\title{
A Comparative Study of Competing Discursive Construction of South China Sea Disputes in the Chinese and US English-Language Newspapers
}

\author{
Dan Zhang ${ }^{1,2}$ \\ ${ }^{1}$ Institute of Tropical Agriculture and Forestry, Hainan University, Danzhou, China \\ ${ }^{2}$ Faculty of Humanities, The Hong Kong Polytechnic University, Kowloon, Hong Kong \\ Correspondence: Dan Zhang, Institute of Tropical Agriculture and Forestry, Hainan University, Danzhou, China. \\ E-mail: 180533@hainanu.edu.cn
}

Received: January 12, 2019 Accepted: February 26, 2019 Online Published: May 23, 2019

doi:10.5539/ells.v9n2p46 URL: https://doi.org/10.5539/ells.v9n2p46

\begin{abstract}
This study examines the discursive construction of South China Sea dispute in China Daily and The New York Times from April 2016 to December 2017. Drawing on Van Dijk's account of critical discourse analysis and the linguistic framework of Appraisal theory (Martin \& White, 2005), this study investigates how three social actors in the dispute, namely China, United States, Philippines, are differently constructed with the strategic use of attitude resources in the two newspapers. The corpus analyzed consists of 45 newspaper texts from China Daily and 49 newspaper texts from The New York Times. The analysis reveals competing discursive construction of social actors that constitute positive us-representation and negative other-representation in the two newspapers. For example, China Daily constructs China as a peace-loving country, insisting on the peaceful means and the cooperation with ASEAN and other claimant countries to resolve the dispute, whereas The New York Times depicts China as threat, hegemony and provocation. Such competing discursive construction not only reflects the ideological stance of two newspapers, but also functions to legitimize their countries' policies and decisions in the South China Sea dispute.
\end{abstract}

Keywords: attitude, critical discourse analysis, media discourse, discursive construction, South China Sea Dispute, social actors

\section{Introduction}

The South China Sea dispute is "one of the most complicated geopolitical issues of the twenty-first century" (Freeman, 2017, p. 1). More than 20 countries and regions have been involved in this conflict, arguing over the area's maritime boundaries and the rights to exploit its possibly extensive reserves of fishing resources and oil. While the issue has existed for many decades, "international news media have tended to cover the mainly territorial disputes through the lens of each incidences' newsworthiness" (Freeman, 2017, p. 1). At the heart of the dispute is China's "nine-dash" line claim. Neighboring countries, such as the Philippines, Vietnam, Malaysia, Brunei, Taiwan and Indonesia, have the overlapping claim to the same area. The United States, without any claims to South China Sea, is involved to the dispute due to the concern of freedom of navigation, historical presence and alliance with other countries.

This hot issue has been extensively reported in the international media to such an extent that the media coverage has an effect on the audiences' awareness and attitude as well as governments' policies (Freeman, 2017). As is with the other conflict of similar kind, the reporting from various international media always involves the representation, interpretation and attitude of the South China Sea dispute. However, the representation of the dispute may be biased, which may align with the political affiliation of the media organization or the stance or the reporter (Baker et al., 2013). Therefore, media coverage of South China Sea dispute and the language use in the reporting results in different interpretation patterns for the understanding of the events, relations and identity (Van Dijk, 2015), which consequently influence the audiences' attitude towards the countries involved in the dispute.

Media coverage of South China Sea dispute has attracted the attention of scholars in communication (Freeman, 2017) and discourse analysts (Chen, 2018; Xin, 2018a, 2018b; Wang, 2017; Zhang, 2017). Chen (2018) 
examines how American media uses news frame to construct the American and Chinese national identity in the media coverage of South China Sea arbitration. Wang (2017) investigates the discursive constructions of national images of the conflicting countries in the news coverage of Manila Times, the Philippines media. The study suggests that the constructed images of conflicting countries in media discourse is a kind of discursive illusion influenced by historical cultural factors and might produce certain social-political impact. Gong and Zhang (2018) examine how US media uses different de/legitimization strategies to construct China's negative image and legitimize their actions in the South China Sea dispute. These studies have shown us how the South China Sea dispute and China are represented in the media discourse, but it seems that most studies take the mono-cultural perspective to analyse US or Philippines media representation of the dispute. Fewer studies pay attention to comparison of different countries' media coverage on South China Sea dispute. As Carvalho (2008) argues, a systematic analysis of the discourse of two conflicting parties in the conflict would help come to an understanding and "making explicit the alignment of news media with a given side and increase awareness of the plurality of views, as well as of the biases both in the media and in social actors' discourses" (p. 162). Previous comparative studies on media discourse on South China Sea issue were conducted based on content analysis with the theory of frame and agenda-setting (Xin, 2018a, 2018b), which failed to pay attention to the role of language in the discursive construction of social actors.

Therefore, this study intends to fill this gap by comparing American and Chinese media coverage of South China Sea dispute following Van Dijk's approach to critical discourse analysis, with a focus on their attitude and ideologies in the discursive construction of different social actors, including China, United States and Philippines.

\section{Literature Review}

Critical discourse analysis views discourse as social practice and holds the view that there is a dialectical relationship between a particular discursive event and context, institution and social structure (Failclough \& Wodak, 1997). CDA aims to explore the relationship between language, ideology and power. As Wodak argues (2001), critical discourse analysis is "fundamentally interested in analyzing opaque as well as transparent structural relationships of dominance, discrimination, power and control as manifested in language", with an aim "to investigate critically social inequality as it is expressed, signalled, constituted, legitimized and so on by language use (or in discourse)" (p. 10). Van Leeuween (2007) suggests there are several discursive strategies that are adopted for legitimating their intentions, actions or decisions, including authorization, moralization, rationalization and mythopoesis. Authorization refers to "legitimization by reference to the law, policies and rules or the people with institutional status". Moralization is the labeling of social actors by reference to value systems, which can be manifested by using evaluative adjective or comparisons. Rationalization is legitimization by reference to the goal, means and outcome of the social action. Mythopoesis is legitimization by means of narrating rewarding practice of social actors and non-legitimate actions with undesirable consequences.

In light of the aims of CDA in exploring the relationship between language, ideology and power, it has been extensively applied to the study of media discourse (Chan, 2012; Fairclough, 1998; Khosravinik, 2009, 2015; Oktar, 2001; Teo, 2000). Critical discourse analysis offers a comprehensive and cohesive theoretical framework and a set of conceptual tools for the analysis of ideology and media discourse (Chan, 2012, p. 363). For example, Khosravinik (2009) investigates media representation of refugees, asylum seekers and immigrants during two major events in British newspapers. The analysis finds that various discursive strategies are adopted to construct the social actors in the events. For example, the immigrants and refugees are defined as "race" problem with the use of different micro-linguistic resources, such as information order, agenda setting, exaggeration, summarization and quotation patterns in particular. Chan (2012) explores discursive construction of ideology and national identity in Chinese and Japanese newspaper reporting of East China Sea dispute. The results show that Chinese reporting invokes a high order of Asian identity that includes Japan and US as "out-group", while Japaneses represents Japan as democratic free world with China as "out-group". He concludes that different representations of the social actors in Chinese and Japanese newspaper reporting of East China Sea dispute may be interpreted as the newspapers' adherence to official narratives and discourses of respective government ( $\mathrm{p}$. 361). Khosravinik (2015) analyses the discursive strategies used in representing the nuclear programme in Iranian daily, Kayhan. The study focuses on patterns of language in use in terms of the representations of Self and Other and argumentation strategies used in legitimating the representations. As shown in the critical discourse analysis of media discourse, news reporting not only imposes certain values on the events or social actors it represents, but also reconstructs the ideological representation of different social events. Additionally, apart from representations, news reporting uses legitimization strategies to explain and justify their representation (Caldas-Coulthard, 2003). 
This study will follow the line of previous studies to investigate the discursive construction of the social actors in Chinese and American news reporting of South China Sea dispute, with a focus on how us and them are represented in the discourse as a means to not only display ideological conflict between them but also to legitimize their policies and decisions.

Specifically, the study intends to answer the following questions:

1) How are social actors constructed differently in the media discourse?

2) What are the similarities and differences in the discursive construction of the social actors in China Daily and The New York Times?

3) How do the positive us-representation and negative other-representation serve as legitimization strategies to justify their policies and decisions?

\section{Analytical Framework and Methodology}

The analytical framework adopted for the study of construction of "us" and "them" is Appraisal theory (Martin $\&$ White, 2005). It offers a comprehensive framework to analyse how the language resources are manipulated by the reporters to evaluate the events or actors they refer to in the production of news texts. Appraisal theory deals with interpersonal meaning at the level of discourse semantics. The appraisal resources are used for negotiating social relationships by expressing how individuals feel about people and things (Martin \& Rose, 2007). It identifies three broad domains to make evaluative meaning: attitude, engagement and graduation. The attitude system, the focus of this study, is further divided into three sub-systems: affect, judgement and appreciation. Affect deals with the resources to express emotions such as happiness, security, satisfaction and inclination. Judgement is concerned with the resources for assessing people's behavior or characters based on some social norms. It consists of two sub-categories: social esteem and social sanction. Social esteem comprises three subsystems: normality (how usual they are), capacity (how capable they are) and tenacity (how dependable they are). Social sanction involves two subsystems of veracity (how truthful they are) and propriety (how ethical they are). Appreciation is concerned with evaluation of products, performances, processes and phenomenon, which comprises three subsystems: reaction, composition and valuation. Reaction is concerned with the emotional impact of the entity on the reader. Composition deals with the evaluations of balance and complexity of the product or process according to various conventions of formal organization. Valuation deals with the assessments of the social significance of the products, objects and processes (Martin 2000, p. 160).

In terms of the realization of attitude, appraisal theory notes that attitude can be expressed not only by explicit attitudinal lexis (e.g., the fear and anger that China's aggressive actions have generated), but also by implicitly recounting the events that elicit attitude. The excerpt 1 exemplifies it:

Excerpt 1. the ruling offers a fresh opportunity to address maritime disputes in a peaceful manner. China's ambassador to the United States, Cui Tiankai, condemned Tuesday's ruling

In the excerpt 1, there is no negative assessment of China for refusing to resolve the dispute in a peaceful manner. Rather, this assessment is activated by recounting the authority of the ruling and China's condemnation of the ruling. In this case, listener may get attitude inference based on their reading position, even if it is the newspaper that positions readers to reach such attitude.

It is worth noting in this regard that appreciation of the effect of behavior has the potential to invoke the assessment of humans, that is judgement. For example,

Excerpt 2. China's construction will benefit all, because it is ready to provide facilities and security assurance for passing ships and offer necessary public goods for the region.

In this case, appreciation of the benefit of China's construction invokes a positive assessment of China who is legal, justified and reasonable in island construction in South China Sea region. These instances will be double coded in the two corpora.

For the comparison of China and United States media coverage on South China Sea dispute, two corpora are compiled with the articles from two newspapers: China Daily and The New York Times. The Chinese corpus encompasses 45 newspaper texts collected from China Daily, while American corpus consists of 49 newspaper texts from the New York Times. The data cover a time span from April 2016 to December 2017, collected from the LexisNexis, a newspaper database with the searching words "South China Sea" or "South Sea". In the analysis of attitude resources used by newspapers to construct different social actors, that is China, United States and Philippines, a corpus-based analysis with manual text analysis will be adopted in this study, since the attitude is realized ranging from words to sentences to paragraphs. In detail, firstly, AntConc, a free corpus 
software, is used for generating the concordance lines of the social actors "China/Chinese", "United States/US" and "Philippines". Table 1 shows the number of concordance lines for the social actors in two corpora. Secondly, all the concordance lines are annotated with the framework of attitude. The attitudinal meaning is annotated not just focusing on this sentence, but also the neighboring sentences. When there is no attitude in the concordance line, it will be annotated as neutral. Thirdly, the distribution of attitudinal resources and realization of attitude are shown to identify how three countries are represented with the use of attitude resources in the two newspapers.

Table 1. The number of concordance lines for social actors in China Daily and The New York Times

\begin{tabular}{lll}
\hline & China Daily & The New York Times \\
\hline China/Chinese & 443 & 383 \\
US & 278 & 229 \\
Philippines & 189 & 234 \\
\hline
\end{tabular}

\section{Findings}

In the analysis of the distribution of attitude resources and how they are realized in the two corpora, two questions will be addressed: 1) How are social actors constructed differently in the media discourse? 2) What are the similarities and differences in the discursive construction of social actors in CD and NYT?

\subsection{Discursive Construction of China in China Daily and The New York Times}

\subsubsection{Discursive Construction of China in China Daily}

Table 2. Attitude resources towards China in China Daily

\begin{tabular}{|c|c|c|c|c|c|c|}
\hline & \multicolumn{2}{|l|}{ positive } & \multicolumn{2}{|l|}{ negative } & \multirow[b]{2}{*}{ Total } & \multirow[b]{2}{*}{$\%$} \\
\hline & explicit & implicit & explicit & implicit & & \\
\hline Affect & 8 & 6 & 5 & 1 & 20 & $6.4 \%$ \\
\hline Judgement & 36 & 155 & 18 & 38 & 247 & $78.9 \%$ \\
\hline Appreciation & 10 & 31 & 2 & 3 & 46 & $14.7 \%$ \\
\hline Total & 246 & & 67 & & 313 & $100 \%$ \\
\hline$\%$ & $78.5 \%$ & & $21.5 \%$ & & & $100 \%$ \\
\hline
\end{tabular}

The distribution of attitude resources in China Daily is shown in Table 2. It can be seen that the salient feature in China Daily is its stress on China's positive qualities, including three aspects: China's determination and capability to resolve the dispute, cooperation with other countries and legality in maintaining sovereignty and territorial integrity. China's capability to maintain peace and stability in the South China Sea dispute is implicitly expressed by recounting the China's principles, polices and efforts and determination, as with examples "China and the ten ASEAN countries reached agreement on the Guidelines for the Implementation of the DOC in 2011"; "China is devoted to continuing to promote peaceful settlement of disputes through negotiations by countries". These implicit judgement resources intend to show that China's international cooperation with other countries has achieved great results and China insists on the path of peaceful development and negotiation in the South China Sea region. Additionally, China's actions and claims in maintaining sovereignty and territorial integrity are legitimized by recounting China's historical rights in the region and adherence to the international law. For example, in example 1, China's sovereignty and claims have been justified and legitimized by implicitly recounting the fact the claims have been formed over long course of history' and use of explicit attitudinal lexis "solid" and "legal". The second most frequent use of attitude is appreciation, in which the close and sound relationship between China and other countries, and the "dual-track" approach are explained. It explains China and relevant countries have had effective, open and smooth communication and dialogue on the South China Sea issue and reached a lot of important common ground, which ushers in the possibility for more diplomatic consultations to solve problem. China's initiative of "dual-track" approach is evaluated as the proper, best way for maintaining peace and stability in the South China Sea. It suggests Chinese tradition of maintaining harmony and achieving equilibrium in international relations. In terms of affect, China is represented with two strategies: praise of its willingness to cooperate with other parties to solve the dispute from external authorities, such as ASEAN and its historical right in South China Sea.

(1) China's sovereignty and claims of rights over Nansha Islands and their adjacent waters in the South China Sea have been formed over the long course of history and have adequate and solid historical and legal basis. 


\subsubsection{Discursive Construction of China in The New York Times}

Table 3. Attitude resources towards China in The New York Times

\begin{tabular}{lllllll}
\hline & positive & \multicolumn{3}{c}{ negative } & & \\
\cline { 2 - 5 } & explicit & implicit & explicit & implicit & Total & $\%$ \\
\hline Affect & 9 & 12 & 26 & 33 & 80 & $24 \%$ \\
Judgement & 12 & 34 & 36 & 123 & 205 & $61.4 \%$ \\
Appreciation & 5 & 11 & 10 & 23 & 49 & $14.6 \%$ \\
Total & 83 & & 251 & & 334 & $100 \%$ \\
$\%$ & $24.9 \%$ & & $75.1 \%$ & & & $100 \%$ \\
\hline
\end{tabular}

Table 3 describes the distribution of attitude resources in the New York Times. It can be seen that American media coverage is dominated with implicit negative appreciation resources in representing China. The salient feature of reporting is negative appreciation of China's actions in the South China Sea region. In terms of expression, the negative appreciation is constructed implicitly by recounting the aim and consequence of China's territorial claim, island construction and resolution to the dispute. Firstly, it points out that China's territorial claims are excessive and aggressive, where the negative evaluation is downplayed by the use of words with numerical statistics, such as claims "much of..., 80\%, 90\%, almost as its own, exclusive, the vast majority of". Secondly, the island construction in the South China Sea is depicted as provocative unilateral action that raises tensions and undermines the prospects for a diplomatic or other peaceful resolution. In terms of expressing this negative judgement, this typically involves with what other countries react to China's actions, implying that its actions are undesirable, as can be seen in the expressions such as "Carter criticized China's actions"; other countries that oppose China's actions; condemning China's "destabilizing, unilateral actions". Another delegitimization strategy to represent China is through the representation of China's inclination to control the region and other countries' dissatisfaction towards China's behavior. For instance, the reporting explains that China is a superpower willing to take unilateral action against its neighbors; never want to yield, to be recognized as a leader. The negative emotions from other countries (rebuke, oppose, reject, criticize etc.) are expressed through recounting the impact of China's behavior as indicated in example (2),

(2) the fear and anger that China's aggressive actions have generated among its maritime neighbors, and the tensions they have raised with Washington

\subsection{Discursive Construction of United States in China Daily and The New York Times}

\subsubsection{Discursive Construction of United States in China Daily}

Table 4. Attitude resources towards United States in China Daily

\begin{tabular}{lllllll}
\hline & positive & \multicolumn{3}{c}{ negative } & \\
\cline { 2 - 5 } & explicit & implicit & explicit & implicit & Total & $\%$ \\
\hline Affect & 3 & 7 & 4 & 13 & 27 & $10.4 \%$ \\
Judgement & 8 & 22 & 4 & 50 & 84 & $13.2 \%$ \\
Appreciation & 10 & 5 & 34 & 99 & 148 & $76.4 \%$ \\
Total & 55 & & 204 & & 259 & $100 \%$ \\
$\%$ & $21.2 \%$ & & $78.8 \%$ & & & $100 \%$ \\
\hline
\end{tabular}

Table 4 shows the distribution of attitude resources for representing United States in China Daily. It can be seen that China Daily uses a large proportion of appreciation recourse to represent United States, rather directly judging its behaviors. The dominant attitude is the negative appreciation resources used for representing the aim and consequence of United States' military presence in the South China Sea. The majority of appreciation instances emphasize US's military presence, exercises and alliance with other countries complicates the situation and makes it more difficult to settle the disputes, which represents United States as an interference in the dispute. This can be evidenced by the co-selection of US and military in 78 concordance lines. Moreover, China Daily also makes negative judgement of US's violation of its commitment of not taking sides in the South China Sea by recounting its aims of the interference in the dispute. It explains that US is aimed at deterring China from expanding its influence, and intends to accomplish Washington's political and diplomatic goals in Asian-Pacific region. In terms of the realization of the negative attitude, it is expressed more implicitly by using the word "urge, 
advise, ask, should" (e.g., We advise the US side to think twice before its actions; We urge the United States to abide by its commitment), which implies that what US is doing is wrong. Despite the confrontation between China and United States in the South China Sea region, it is noteworthy that in China Daily, there are some positive appreciation instances to recount the cooperation between China and United States, which suggests that the two countries also have a positive mode of cooperation and supplement each other on some world issues (e.g., the China-US relationship is developing on a steady track; China and the United States have also cooperated in confronting world challenges, including natural disasters and other humanitarian crises).

\subsubsection{Discursive Construction of United States in The New York Times}

Table 5. Attitude resources towards United States in The New York Times

\begin{tabular}{|c|c|c|c|c|c|c|}
\hline & \multicolumn{2}{|l|}{ positive } & \multicolumn{2}{|l|}{ negative } & \multirow[b]{2}{*}{ Total } & \multirow[b]{2}{*}{$\%$} \\
\hline & explicit & implicit & explicit & implicit & & \\
\hline Affect & 13 & 5 & 3 & 2 & 23 & $12.1 \%$ \\
\hline Judgement & 38 & 66 & 0 & 5 & 109 & $67.9 \%$ \\
\hline Appreciation & 4 & 17 & 18 & 19 & 58 & $20 \%$ \\
\hline Total & 153 & & 37 & & 190 & $100 \%$ \\
\hline$\%$ & $80.5 \%$ & & $19.5 \%$ & & $100 \%$ & $\%$ \\
\hline
\end{tabular}

The distribution of attitude resources in the concordance lines with "United States" in The New York Times is shown in Table 5. The salient feature of the report is positive judgement of United States' role in the dispute. In terms of realization, firstly, explicit positive attitudinal lexis is used to depict United States as a dominant, justified and powerful country in Asia-Pacific region (e.g., dominant, strong, naval power, neutral, legal). Secondly, the implicit attitude is used for highlighting legitimacy of US's involvement in the dispute and its "facilitator" role in resolving the dispute. The strategy most frequently used for construction of legitimacy is assignment of different semantic role for United States in the reporting. When "US" is in the semantic patient in the sentence, it is represented as a country who is forced or allowed. This is mediated through the permission of the international law, Philippines or China, which implies that US's activity is lawful and justified in accordance with international law and agreement, as indicated in examples (3) and (4).

(3) The new agreement allows the United States to operate only within Philippine military facilities

(4) Some nations, like the Philippines, an American ally, and Vietnam, a former enemy, have asked the United States for more military assistance since China's policy on the South China Sea has hardened

When US occupies the agent role, it is mainly related to US's neutrality and constructive role in facilitating other countries resolving the dispute through negotiation, as in the example "the United States takes no position on the competing territorial claims", "the United States would fulfill its obligations under a mutual defense treaty". In this case, United States is represented as an impartial, justified and righteous country. Another strategy for projecting positive image of United States is the representation of relationship between China, Philippines and United States with appreciation resources. When it comes to the relationship between China and United States, it is described as "clashing, heightened, fractious, serious, difficult", which suggests that China's aggressive behaviors and rising power are the main cause of the conflict between US and China in the context. In contrast, the relationship between Philippines and United States are explicitly described as "alliance", "partners", which serves to legitimize US's interference in the dispute and its claim to keep its treaty to protect Philippines.

\subsection{Discursive Construction of Philippines in China Daily and The New York Times}

\subsubsection{Discursive Construction of Philippines in China Daily}

Table 6. Attitude resources towards Philippines in China Daily

\begin{tabular}{lllllll}
\hline & positive & \multicolumn{5}{c}{ negative } \\
\cline { 2 - 5 } & explicit & implicit & explicit & implicit & Total & $\%$ \\
\hline Affect & 2 & 3 & 5 & 3 & 13 & $8.3 \%$ \\
Judgement & 3 & 8 & 20 & 74 & 105 & $67.3 \%$ \\
Appreciation & 5 & 9 & 9 & 15 & 38 & $24.4 \%$ \\
Total & 30 & & 126 & & 156 & $100 \%$ \\
$\%$ & $19.2 \%$ & & $80.8 \%$ & & & $100 \%$ \\
\hline
\end{tabular}


Table 6 shows the distribution of attitude resources in the concordance lines with Philippines. It can be seen that judgement and appreciation resources take a large proportion. Firstly, judgement resources are used to judge the Philippine's illegal occupation of China's islands, Philippine's unilateral behavior of issuing the arbitration request and the purpose of Philippine action. It points out that Philippine's action doesn't accord with the rules given by UNCLOS (United Nations Convention on the Law of the Sea) and Philippine's motive is to snatch and illegally seize China's territory. Another strategy to provoke the negative attitude towards the Philippines is to appreciate the nature of the arbitration tribunal in a negative way. From example (5), it can be seen that by defining the arbitration as "having no jurisdiction", it implies that the result of ruling by the tribunal has no legal basis and China's non-participation into the proceedings is legitimized.

(5) the Arbitral Tribunal manifestly has no jurisdiction in this case and to demonstrate that China's position not to accept or participate in the proceedings stands on solid ground in international law.

4.3.2 Discursive Construction of Philippines in The New York Times

Table 7. Attitude resources towards Philippines in The New York Times

\begin{tabular}{|c|c|c|c|c|c|c|}
\hline & \multicolumn{2}{|l|}{ positive } & \multicolumn{2}{|l|}{ negative } & \multirow[b]{2}{*}{ Total } & \multirow[b]{2}{*}{$\%$} \\
\hline & explicit & implicit & explicit & implicit & & \\
\hline Affect & 5 & 9 & 9 & 15 & 38 & $24.4 \%$ \\
\hline Judgement & 3 & 8 & 20 & 74 & 105 & $67.3 \%$ \\
\hline Appreciation & 2 & 3 & 5 & 3 & 13 & $8.3 \%$ \\
\hline Total & 30 & & 126 & & 156 & $100 \%$ \\
\hline$\%$ & $19.2 \%$ & & $80.8 \%$ & & & $100 \%$ \\
\hline
\end{tabular}

For the representation of Philippines in The New York Times, it is worth noting that in the 234 concordance lines, only 156 concordance lines convey attitudinal expressions, which indicates that The New York Times may take a neutral attitude towards Philippines. Table 7 shows that the dominant attitude is judgement, which is used to emphasize vulnerability of Philippines and its legal claims in the South China Sea. In terms of realization, similar to China Daily, the concordance lines with "Philippines" are mainly dominated by negative attitude. However, the negative attitude lexis is used for describing Philippines' incapability and weakness in facing the great power of China (e.g., seized, controlled, small). Instead of using explicit attitudinal lexis, Philippines is represented as challenged by recounting the fact that Philippine fishing men are expelled and seized by China. And Philippine claims are represented as legal by recounting its historical rights and basis on the international law. For example, the example (6) clearly shows that Philippine claim is legal and justified since it is set by UNCLOS. Another strategy for provoking the negative attitude towards China is the representation of negative emotions from Philippines. The emotions include the reactions of Philippines (anger, be concerned about, nervous, accuse, etc) towards China's actions and their eagerness and willingness to welcome US's countermeasure towards China.

(6) The current Philippine claim is based in part on a presidential decree from 1978 but mostly on terms set by the United Nations Convention on the Law of the Sea (Unclos) from 1982, which established Exclusive Economic Zones (E. E. Z.) of 200 nautical miles off the coast of sovereign states

\section{Discussion and Conclusion}

Focusing on the discursive construction of three social actors in the Chinese and American media coverage of South China Sea dispute, this study explores how different versions of reality are constructed by two opposing media discourse with the strategic use of attitude resources. The attitude resources in the media coverage not only reflect the ideologies of the two newspapers, but also serves as the rhetoric tool to legitimate their countries' policy and actions and inform how readers have an understanding of the dispute.

The analysis reveals a contrasting representation of the reality. In China Daily, China is portrayed as a peace-loving country, insisting on the peaceful means and the cooperation with ASEAN and other claimant countries to resolve the dispute. United States is depicted as an interference which complicates the situation of South China Sea dispute and Philippines as a violator of international law. Such representation may have an influence on readers' attitude towards China's claims and actions. In the New York Times, in contrast to the reality constructed by China Daily, China is negatively represented as threat, hegemony and provocation, while US plays a role in facilitating the Philippines, which is a vulnerable country with legal claims to resolve the dispute. 
The contrasting construction of social actors in the two newspapers reveals that institutions construct an ideological image of us and them in such a way that us is represented in a positive way while them is represented in a negative way (Van Dijk, 1998, p. 68). CDA aims to investigate the ideology and power which is expressed, constituted, legitimized by language. In this sense, the positive self-representation and negative other-representation with the attitude resources in this study functions as the discursive strategies to legitimate speaker's policy and actions, while delegitimating alternative options (Van Dijk, 2009) in the media coverage through authorization, moralization and rationalization (Van Leeuwen, 2007).

In China Daily, in the positive us-representation, China's positive qualities, including its capability, cooperation and legality in the region are highlighted, which intends to legitimate China's policy in the South China Sea region by reference to moral evaluation. China Daily also stresses the positive consequences of China's policy and approaches (rationalization), aiming to demonstrate China's approach contributes to the resolution of South China Sea dispute in a peaceful and effective way and the idea that China's non-negotiation and violence raises tension between countries is delegitimized. In the negative other-representation, Philippines' behaviors are delegitimized by emphasizing the nature of tribunal it resorts to (authorization). Philippines is also negatively represented as violator of international law by emphasizing its illegal occupation (moral evaluation). For United States, its military operations with Philippines are delegitimized by recounting its negative consequence and aim of its actions (rationalization). Therefore, in the China's media coverage, the delegitimization of United States and Philippines' actions in the region allows China to legitimize its territorial claims, island construction and one-to-one negotiation approach in the dispute.

In the New York Times, in the negative other-representation, China's actions and claims are delegitimized by highlighting the dissatisfaction of experts or leaders from all the countries involved in the dispute as well as non-recognition from international law (authorization). Another delegitimization strategy is the recounting of impact and aim of China's territorial claim and island construction (rationalization), presenting China as threat, hegemony and provocation in the dispute. In the positive us-representation, Philippines is constructed as vulnerable but with legal claims by reference to the comparison (emotional evaluation) with China and emphasis of its historical rights in the South China Sea dispute (authorization). The discursive construction of China and Philippines' role in the dispute legitimates United States' legitimacy and facilitator role in the dispute, which is achieved by stressing its adherence to international law and freedom of navigation (authorization).

In summary, adopting critical discourse analysis approach, this study examines how the social actors are differently constructed with attitudinal resource in the two competing media discourse and how these attitudinal resources function as rhetoric tools to legitimate the policy and actions of their country. Significant variation in the construction of social actors and South China Sea dispute has been found in the two newspapers. The competing discursive construction of social actors and the events in Chinese and American media discourse informs us newspapers' manipulation of attitude to construct and engage the reader with their ideologies, which are embedded into the media to legitimize the actions taken by their country and protect their national interest. In order to get a more comprehensive picture of construction of countries in the media, the future research could be extended to the analysis of participant roles of each country by examining the process types and semantic roles assigned to each country with the transitivity analysis.

\section{Acknowledgments}

This study is supported by the Philosophy and Social Science Project of Hainan Province under Grant HNSK(QN) 16-131.

\section{References}

Baker, P., Gabrielatos, C., \& McEnery, T. (2013). Discourse analysis and media attitudes: The representation of Islam in the British press. Cambridge University Press. https://doi.org/10.1017/CBO9780511920103

Caldas-Coulthard, C. R. (2003). Cross-cultural representation of 'otherness' in media discourse. In G. Weiss \& R. Wodak (Eds.), Critical discourse analysis (pp. 272-296). Basingstoke: Palgrave Macmillan. https://doi.org/10.1057/9780230288423_13

Carvalho, A. (2008). Media (ted) discourse and society: Rethinking the framework of critical discourse analysis. Journalism Studies, 9(2), 161-177. https://doi.org/10.1080/14616700701848162

Chan, M. (2012). The discursive reproduction of ideologies and national identities in the Chinese and Japanese English-language press. Discourse \& Communication, 6(4), 361-378. https://doi.org/10.1177/1750481312457496 
Chen, Y. (2018). Analysis on the relationship of "Self" and "Other": Media opinions and national identity representations in the reports on the South China Sea. Asia-Pacific Security and Maritime Affairs, 9, 18-33.

Fairclough, N., \& Wodak, R. (1997). Critical Discourse Analysis. In T. A. van Dijk (Ed.), Discourse as Social Interaction (pp. 258-284). London: Sage.

Freeman, B. C. (2017). South China, East Vietnam or West Philippine? Comparative framing analysis of regional news coverage of Southeast Asian Sea disputes. In SHS Web of Conferences (Vol. 33, p. 00020). Les Ulis: EDP Sciences. https://doi.org/10.1051/shsconf/20173300020

Gong, S., \& Zhang, R. (2018). A corpus-based study of delegitimization strategies in US official report of South China Sea disputes. Foreign Language Research, 1, 13-18. https://doi.org/10.13978/j.cnki.wyyj.2018.01.003

KhosraviNik, M. (2009). The representation of refugees, asylum seekers and immigrants in British newspapers during the Balkan conflict (1999) and the British general election (2005). Discourse \& Society, 20(4), 477-498. https://doi.org/10.1177/0957926509104024

KhosraviNik, M. (2015). Macro and micro legitimation in discourse on Iran's nuclear programme: The case of Iranian national newspaper Kayhan. Discourse \& Society, 26(1), 52-73. https://doi.org/10.1177/0957926514541345

Martin, J. R., \& Rose, D. (2007). Interacting with text: The role of dialogue in learning to read and write. Foreign Languages in China, 4(5), 66-80. https://doi.org/10.13564/j.cnki.issn.1672-9382.2007.05.010

Martin, J. R., \& White, P. R. (2003). The language of evaluation (Vol. 2). London: Palgrave Macmillan. https://doi.org/10.1057/9780230511910

Oktar, L. (2001). The ideological organization of representational processes in the presentation of us and them. Discourse \& Society, 12(3), 313-346. https://doi.org/10.1177/0957926501012003003

Teo, P. (2000). Racism in the news: A critical discourse analysis of news reporting in two Australian newspapers. Discourse \& Society, 11(1), 7-49. https://doi.org/10.1177/0957926500011001002

Van Dijk, T. A. (1998). 'Opinions and Ideologies in the Press'. In A. Bell \& P. Garrett (Eds.), Approaches to Media Discourse (pp. 21-62). Oxford: Blackwell.

Van Dijk, T. A. (2009). Critical discourse studies; A sociocognitive approach. In R. Wodak \& M. Meyer (Eds.), Methods of Critical Discourse Analysis (pp. 62-85). London: Sage.

Van Dijk, T. A. (2015). Critical discourse analysis. In D. Schriffen, D. Tannen \& H. Hamilton (Eds.), The Handbook of Discourse Analysis (pp. 352-371). Oxford: Blackwell. https://doi.org/10.1002/9781118584194

Van Leeuwen, T. (2007). Legitimation in discourse and communication. Discourse \& Communication, 1(1), 91-112. https://doi.org/10.1177/1750481307071986

Wang, X. (2017). Discursive illusions in Sino-PH sea rows: Cultural discourse approach to news discourse in Manila. Journal of PLA University of Foreign Languages, 4, 10-17.

Wodak, R. (2009) Critical Discourse Analysis: History, Agenda, Theory, and Methodology. In R. Wodak \& M. Meyer (Eds.), Methods of Critical Discourse Analysis (pp. 1-33). London: Sage.

Xin, B. (2018a). Framing analysis of the Sino-American news reports on the South China Sea disputes. Foreign Language Research, 3, 20-26. https://doi.org/10.16263/j.cnki.23-1071/h.2018.03.004

Xin, B. (2018b). An analysis of the agenda-setting function of Sino-American news reports on the South China Sea disputes. Contemporary Rhetoric, 5, 45-53. https://doi.org/10.16027/j.cnki.cn31-2043/h.2017.05.007

\section{Appendix}

One sample from The New York Times corpus

\section{Testing the Rule of Law in the South China Sea}

July 12, 2016

How China reacts to the sweeping legal defeat over its claims to the South China Sea will tell the world a lot about its approach to international law, the use - measured or otherwise - of its enormous power, and its global ambitions. So far, the signs are troubling. Beijing has defiantly rejected an international arbitration court's 
jurisdiction over a case brought by the Philippines and insisted it will not accept Tuesday's pathbreaking judgment.

The unanimous ruling, by a five-judge tribunal in The Hague, was more favorable toward the Philippines and broader in scope than experts had predicted. It said that under the United Nations Convention on the Law of the Sea, China had no legal basis to claim historic rights over most of the waterway, which is rich in resources and carries $\$ 5$ trillion in annual trade.

The panel also faulted China for its aggressive attempts to establish sovereignty by shipping tons of dirt to transform small reefs and rocks into artificial islands with airstrips and other military structures. China's neighbors fear that it intends to use these outposts to restrict navigation and the rights of others to fish and explore for oil and gas.

The Philippines filed the case in 2013 after China took control of a reef known as Scarborough Shoal. The case accused Beijing of interfering with fishing, endangering ships and failing to protect marine life. Manila also asked the tribunal to reject China's claims to sovereignty within a so-called nine-dash line that encompasses much of the South China Sea and appears on official Chinese maps.

The judges ruled for the Philippines on most claims in its complaint: China had indeed violated international law by causing "irreparable harm" to the marine environment, endangering ships and interfering with Philippine fishing and oil exploration. Further, China had illegally built an artificial island on Mischief Reef, complete with a military airstrip, in waters belonging to the Philippines.

The Law of the Sea treaty sets rules for establishing zones of control over the oceans based on distances to coastlines. In addition to China and the Philippines, Malaysia, Vietnam, Brunei, Indonesia and Taiwan all claim parts of the South China Sea. The tribunal is authorized to deal with maritime disputes, not the underlying land claims to the islands, reefs and rocks that are also contested. The decision is the first international ruling on the disputed maritime issues in the South China Sea.

There are serious concerns about what will happen next. The tribunal has no authority to enforce its ruling, and China, which boycotted the legal process, threatens to use force to protect the maritime interests the court has now declared illegal.

What this means in practice is not clear. Given China's stake in peaceful trade with the rest of the world, it would be foolish for President $\mathrm{Xi}$ Jinping to take provocative actions that could inflame regional tensions and conceivably lead to a military confrontation with its neighbors or the United States. Retaliatory measures - further island-building at Scarborough Shoal, for instance, or declaring an air defense zone over large portions of the South China Sea - would be risky.

In fact, the ruling offers a fresh opportunity to address maritime disputes in a peaceful manner. China's ambassador to the United States, Cui Tiankai, condemned Tuesday's ruling but said Beijing remains open to negotiations. Nations in the region have often gone wobbly in the face of pressure from Beijing. At this critical moment, despite competing interests of their own, they need to join the Philippines in endorsing the tribunal decision and then proceed, if necessary, with their own arbitration cases.

\section{One sample from China Daily corpus}

\section{The Tribunal's Award in the 'South China Sea Arbitration' Initiated by the Philippines Is Null and Void}

June 11,2016

On 10 June 2016, the Chinese Society of International Law (CSIL) released a paper entitled The Tribunal's Award in the "South China Sea Arbitration" Initiated by the Philippines Is Null and Void. The executive summary of the paper is as follows:

On 22 January 2013, the Philippines unilaterally initiated arbitration with respect to certain issues in the South China Sea ("Arbitration"). China has maintained its solemn position that it would neither accept nor participate in the Arbitration, having stated that the tribunal constituted at the unilateral request of the Philippines ("Arbitral Tribunal" or "Tribunal") manifestly has no jurisdiction.

On 29 October 2015, the Tribunal issued its Award on Jurisdiction and Admissibility ("Award on Jurisdiction" or "Award"), in which it found that it had jurisdiction over some of the Submissions made by the Philippines, and reserved consideration of its jurisdiction with respect to the other Submissions to the merits phase. This finding is full of errors in both the determination of fact and the application of law. 


\section{Copyrights}

Copyright for this article is retained by the author, with first publication rights granted to the journal.

This is an open-access article distributed under the terms and conditions of the Creative Commons Attribution license (http://creativecommons.org/licenses/by/4.0/). 